\title{
Treynor Ratio to Measure Islamic Stock Performance in Indonesia
}

\author{
Mohammad Farhan Qudratullah \\ Program Studi Matematika Fakultas Sains dan Teknologi, UIN Sunan Kalijaga, Jl. Marsda Adisucipto \\ No. 1 Yogyakarta, Indonesia \\ Korespondensi; Email: mohammad.qudratullah@uin-suka.ac.id; aching_lo@yahoo.com
}

\begin{abstract}
Abstrak
Treynor Ratio merupakan model pioner inovatif ukuran kinerja saham yang dikemukakan Jack Treynor pada tahun 1965 yang terdiri atas 3 (tiga) komponen, yaitu return saham, return bebas risiko, dan beta saham. Banyak penelitian mendekati return bebas risiko dengan suku bunga termasuk saat mengukur kinerja saham syariah, sedangkan suku bunga dilarang dalam konsep keuangan islam. Tulisan ini membahas variabel alternatif untuk mendekati return bebas risiko selain dengan suku bunga (BI-Rate), yaitu dengan 4 (empat) pendekatan, yaitu: menghilangkan suku bunga, mengganti dengan zakat rate, mengganti dengan inflasi, dan mengganti dengan gross domestic produc (GDP) pada model Treynor Ratio yang diimplementasikan pada pasar modal syariah di Indonesia periode Januari 2011-Juli 2018. Hasil yang diperoleh adalah terdapat kesesuaian yang sangat tinggi hasil pengukuran model Treynor Ratio dengan suku bunga dengan keempat model lainnya. Namun, model-model tersebut tidak menjamin bahwa saham yang memilki kinerja terbaik pada saat ini akan memilki kinerja terbaik dimasa yang akan datang atau sebaliknya. Dilihat dari kedekatan hasil pengukuran kinerjanya, kelima model Treynor Ratio tersebut dapat dikelompokan jadi 2 (dua), yaitu model dengan suku bunga, model dengan inflasi, dan model dengan GDP sebagai kelompok pertama, sedangkan model tanpa suku bunga dan model dengan zakat-rate sebagai kelompok kedua.
\end{abstract}

Kata Kunci: Islamic Finance; Islamic Performance Stock; Risk Free Return; Treynor Ratio

\begin{abstract}
Treynor Ratio is an innovative pioneer model the size of stock performance proposed by Jack Treynor in 1965 which consists of 3 (three) components, namely stock returns, risk free returns, and stock beta. Many studies approach risk-free returns with interest rates, including when measuring the performance of Islamic stocks, while interest rates are prohibited in the concept of Islamic finance. This paper discusses alternative variables to approach risk-free returns other than interest rates (BI-Rate), namely with 4 (four) approaches, namely: eliminating interest rates, changing zakat rates, changing inflation, and substituting gross domestic products (GDP) in the Treynor Ratio model that is implemented in the Islamic capital market in Indonesia for the period January 2011 - July 2018. The results obtained are very high conformity in the measurement results of the Treynor Ratio model with interest rates with the other four models. However, these models do not guarantee that stocks that have the best performance at this time will have the best performance in the future or vice versa. Judging from the closeness of the results of performance measurement, the five Treynor Ratio models can be grouped into 2 (two), namely models with interest rates, models with inflation, and models with GDP as the first group, while models without interest rates and models with zakat-rate as second group.
\end{abstract}

Keywords: Islamic Finance; Islamic Performance Stock; Risk Free Return; Treynor Ratio

\section{Pendahuluan}

Investasi dapat dibedakan menjadi 2 (dua), yaitu investasi sektor real dan investasi sektor finansial. Salah satu bentuk investasi sektor finansial yang marak seiring makin berkembangnya perdagangan global dan majunya teknologi informasi adalah investasi saham di pasar modal. Negara yang pertama kali mengimplementasikan prinsip syariah di sektor pasar modal adalah Jordan pada tahun 1978 dan Pakistan pada tahun 1980. Saat ini, reksa dana islami beroperasi terutama di Negara Saudi Arabia, 
UAE, Bahrain, Kuwait, Qatar, Pakistan, Malaysia, Brunei, Singapura, Jerman, Inggris, Amerika Serikat, Kanada, Swiss, dan Afrika Selatan (Ayub, 2009).

Di Indonesia, sejak PT. Bursa Efek Jakarta (BEJ) menerbitkan daftar reksadana, saham, dan obligasi syariah dalam Jakarta Islamic Index (JII) pada 3 Juli 2000 yang ditindaklanjuti dengan penandatanganan nota kesepahaman antara BAPEPAM dengan Dewan Syariah Nasional - Majelis Ulama Indonesia (DSNMUI) tentang prinsip pasar modal syariah pada tanggal 14 dan 15 Maret 2003, pasar modal syariah mengalami perkembangan cukup signifikan dan menunjukan potensi pengembangan dari tahun ke tahun. Dari 2011 Juni 2018, tercatat bahwa kapitalisasi saham syariah di Bursa Efek Indonesia meningkat lebih dari 74\% dari 1968 Triliun menjadi 3428 Triliun, sementara jumlah emitem saham syariah meningkat 64\% dari 234 emitem manjadi 383 emitem (OJK, 2018).

Investasi saham pada pasar modal termasuk pada saham syariah merupakan investasi yang memilki risiko tinggi tetapi memiliki tingkat keuntungan yang tinggi pula (high risk-high return) (Jogiyanto, 2007). Jika tidak berhati-hati, investasi di bursa saham memungkinkan terjadinya kebangkrutan, sehingga untuk mencegah masalah tersebut perlu adanya manajemen risiko. Terdapat beberapa 4 (empat) cara mengelola risiko, yaitu menerima risiko, menghindari risiko, mengendalikan risiko, dan mengalihkan risiko (Baturapan, 2000). Mengendalikan risiko merupakan suatu usaha menangani risiko dengan mengurangi kemungkinan dampak kerugian yang lebih besar. Pada investasi saham, starategi yang direkomendasikan adalah diferensiasi saham dengan membentuk suatu portofolio.

Salah satu masalah terbuka dalam membentuk portofolio adalah bagaimana memilih saham-saham pembentuk portofolio dari sekian banyak saham yang ada? Secara umum, saham yang dipilih adalah saham yang memiliki kinerja terbaik. Analisis kinerja suatu saham dapat dilakukan dengan 2 (dua) cara, yaitu analisis fundamental berdasarkan laporan keuangan dan analisis tehnikal berdasarkan data time series harga perdagangan saham tersebut.

Penelitian tentang analisis kinerja saham, pertama kali dikemukakan oleh Fried, Brown, Herma, dan Vickers dalam tulisannya 'A Study of Mutual Found' pada tahun 1962 (Redman, Gullet, \& Manakyan, 2000). Beberapa tahun kemudian secara terpisah Treynor (1965), Sharpe (1966), dan Jensen (1968) memperkenalkan model untuk mengukur kinerja saham. Sejak itu, pengembangan model untuk mengukur kinerja saham telah banyak dilakukan dan menghasilkan lebih dari 100 alternatif model khususnya model ukuran kinerja yang disesuaikan dengan risiko (Wiesinger, 2010).

Jack Treynor merupakan pioner yang mempelopori model inovatif ukuran kinerja saham pada tahun 1965 yang modelnya dikenal dengan Treynor Ratio. Treynor Ratio terdiri atas 3 (tiga) komponen, yaitu return saham, return bebas risiko, dan risiko pasar yang diukur dengan beta saham. Banyak penelitian yang telah mengunakan Treynor Ratio untuk mengukur kinerja saham syariah di Indonesia, biasanya dikombinasikan dengan Sharpe Ratio dan Indeks Jansen, seperti (Utami, et. al., 2011; Hasbullah, et. al., 2013; Setiawan dan Oktariza, 2013; Andhyka, 2017). Terdapat juga penelitian yang membandingkan kinerja saham syariah dan saham konvensional (Hanafi dan Hanafi, 2012; Hamzah dan Yohanes, 2013; Lestari, 2015; Kusumawati, 2016; Huda, et al,. 2017;). Return bebas risiko dalam penelitian-penelitian tersebut masih didekati dengan suku bunga, yaitu Sertifikat Bank Indonesia atau BI Rate.

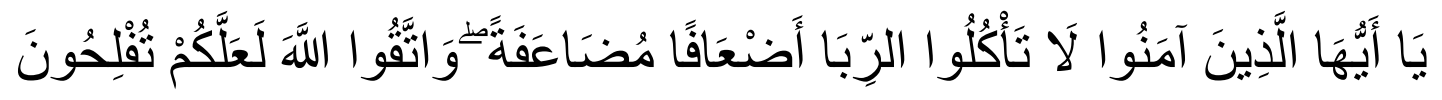

Artinya: "Hai orang-orang yang beriman, janganlah kamu memakan riba dengan berlipat ganda dan bertakwalah kamu kepada Allah supaya kamu mendapat keberuntungan".

Penggunaan suku bunga tidak sesuai dengan konsep keuangan islam, karena suku bunga digolongkan sebagai riba dan riba dengan tegas dilarang dalam Al-Quran (QS. Al-Imran (130)). Beberapa peneliti di Indonesia (Kurniawan dan Asandimitra, 2014; Rumintang dan Azhari, 2015; Djaddang dan Susilawati, 2016) mendekati return bebas risiko menggunakan Sertifikat Bank Indonesia Syariah (SBIS) atau Simpanan Wadiah Bank Indonesia Syariah (SWBI) dalam mengukur kinerja saham syariah. Sedangkan beberapa peneliti luar negeri mendekatinya dengan suku bunga di negaranya seperti Kuala Lumpur Inter Bank Offered Rate (KLIBOR) (Mansor dan Bhatti, 2011), Saudi Inter Bank Offered Rate (SIBOR) (Merdad, et. al., 2010; Ashraf, 2013). 
Usaha mengganti mencari variabel penganti return bebas risiko pada model Capital Asset Pricing Model (CAPM) yang sesuai dengan syariah telah dilakukan oleh Tomkin dan Karim (1987) dengan menghilangkan variabel suku bunga, el-Askhar (1987) mengganti dengan zakat rate, Sheikh (2010) mengganti dengan nominal gross domestic product growth, dan Hanif (2011) mengantinya dengan inflasi yang selanjutnya dikenal denganmodel Sharia Complian Asset Pricing Model (SCAPM) atau Islamic Capital Asset Pricing Model (ICAPM).

Untuk itu, tulisan ini akan membahas pengukuran kinerja saham syariah dengan model Treynor Ratio menggunakan 4 (empat) pendekatan variabel return bebas risiko selain suku bunga dengan melakukan, yaitu: menghilangkan variabel suku bunga tersebut, mengganti dengan zakat rate, mengganti dengan inflasi, dan mengganti dengan gross domestic produc (GDP, kemudian membandingkan dengan model Treynor Ratio dengan suku bunga (BI-Rate) pada Bursa Efek Indonesia (BEI), yaitu saham-saham syariah yang tergabung dalam Jakarta Islamic Index (JII) periode Januari 2011 - Juli 2018.

\section{Kajian Teoritik}

\section{Pasar Modal Syariah di Indonesia}

\begin{tabular}{|c|}
\hline \multicolumn{2}{|c|}{ Seleksi Syariah } \\
\hline $\begin{array}{c}\text { Emiten tidak menjalankan usaha perjudian/permainan yang } \\
\text { tergolong judi, dan perdagangan yang dilarang }\end{array}$ \\
\hline $\begin{array}{c}\text { Tidak memproduksi, mendistribusikan, dan menyediakan barang/ } \\
\text { jasa yang merusak moral dan bersifat mudharat }\end{array}$ \\
\hline \multicolumn{2}{|c|}{ Seleksi Syariah } \\
\hline Sroses ini menyaring 60 saham dengan nilai kapialis pasar \\
tertinggi di Bursa Efek Indonesia (BEI)
\end{tabular}

Sumber: Sudarsono, H. (2003).

Gambar 1. Seleksi Saham Jakarta Islamic Index (JII).

Pada tanggal 3 Juli 2000, PT Bursa Efek Indonesia bekerjasama dengan PT Danareksa Invesment Management (DIM) meluncurkan indeks saham yang dibuat berdasarkan syariah Islam, yaitu Jakarta Islamic Index (JII). Indeks ini diharapkan menjadi tolak ukur kinerja saham-saham yang berbasis syariah serta untuk lebih mengembangkan pasar modal syariah. JII terdiri atas 30 saham yang terpilih dari saham-saham yang sesuai dengan syariah Islam yang pemilihan sahamnya dilakukan oleh BappepamLK bekerjasama dengan Dewan Syariah Nasional (DSN) setiap 6 bulan melalui 2 tahap, yaitu seleksi syariah dan seleksi nilai volume transaksi.

\section{Return dan Risiko}

Hal mendasar dalam keputusan investasi adalah tingkat keuntungan yang diharapkan (return) dan risiko (risk) (Tandelilin, 2001). Return adalah hasil (tingkat pengembalian) yang diperoleh sebagai akibat dari investasi yang dilakukan. Ada beberapa jenis return yang biasa digunakan dalam perhitungan, yaitu simple net return $\left(r_{t}\right)$ dan geometrik return atau log return $\left(R_{t}\right)$.

$$
r_{t}=\frac{P_{t}+D_{t}}{P_{t-1}}-1
$$




$$
R_{t}=\ln \left(\frac{P_{t}+D_{t}}{P_{t-1}}\right)
$$

dimana,

$r_{t} \quad$ : simple net return pada periode $t$

$R_{t} \quad$ : log return pada periode $t$

$P_{t} \quad$ : nilai asset pada periode $t$

$P_{t-1} \quad$ : nilai asset pada periode $t-1$

$D_{t} \quad$ : deviden pada periode $t$

Dari persamaan (1) dan (2) dapat diperoleh hubungan log return dan simple net return, yaitu: $R_{t}=\ln \left(r_{t}+1\right)$. Jika terdapat $T$ observasi, maka ekspetasi return ditulis:

$$
E\left(R_{t}\right)=\bar{R}_{t}=\frac{\sum_{t=1}^{T} R_{t}}{T}
$$

dimana: $E\left(R_{t}\right)$ expected return saham.

Risiko didefinisikan sebagai variabilitas return terhadap return yang diharapkan (Van Horne dan Wachowics, Jr., 1992). Untuk menghitung risiko, metode yang banyak digunakan adalah standar deviasi.

dimana: $\sigma_{t}$ standar deviasi saham.

$$
\sigma_{t}=\frac{\sum_{t=1}^{T}\left(R_{t}-\bar{R}_{t}\right)^{2}}{T-1}
$$

Selain standar deviasi, risiko dapat diukur menggunakan beta saham. Beta saham adalah risiko pengukur risiko sistematik dari suatu saham relatif terhadap risiko pasar (Jogiyanto, 2007).

Dimana:

$$
\beta_{t}=\frac{\operatorname{Cov}\left(R_{t} ; R_{m}\right)}{\operatorname{Var}\left(R_{m}\right)}
$$

$$
\begin{array}{ll}
\beta_{t} & \text { : beta saham } \\
R_{m} & \text { : return pasar }
\end{array}
$$

\section{Treynor's Ratio}

Treynor (1965) mengevaluasi kinerja saham atau portofolio dengan menggunakan Average Return masa lalu sebagai Expected Return dan mengunakan Beta sebagai tolak ukur risiko, berikut rumusannya:

Dimana:

$$
R / V_{T}=\left(\bar{R}_{t}-\bar{R}_{f}\right) / \beta_{t}
$$

$R / V_{T}$ : reward to volatility model Treynor

$\bar{R}_{f} \quad$ : risk free rate

Jika berdiri sendiri, Treynor Ratio tidak akan berguna karena tidak memberi informasi apapun. Treynor Ratio suatu saham akan berarti jika terdapat nilai Traynor Ratio saham lain, saham yang kinerjanya lebih baik adalah saham yang memilki nilai Traynor Ratio lebih besar.

\section{Metodelogi}

Data yang digunakan dalam penelitian ini adalah data bulanan periode Januari 2011 - Juli 2018 yang dibagi menjadi 3 (tiga) kelompok, yaitu data pertama periode Januari 2011 - Desember 2015 dan data kedua periode Januari 2016 - Juli 2018. Data tersebut terdiri atas data harga penutupan saham syariah 
yang konsisten tergabung dalam Jakarta Islamic Index (JII) periode Januari 2011 - Desember 2015, data Indeks Harga Saham Gabungan (IHSG), data Sertifikat Bank Indonesi (SBI) atau BI-Rate, Zakat Rate, Inflasi, dan gross domestic produc (GDP).

Berikut langkah-langkah analisis datanya:

1. Hitung return bulanan saham terpilih dan return pasar (IHSG) dengan persamaan (2) untuk setiap kelompok data

2. Hitung nilai return ekspektasi saham dan pasar menggunakan persamaan (3), serta risiko saham yang terdiri atas standar deviasi dan beta saham dengan persamaan (4) dan (5).

3. Hitunglah nilai kinerja saham menggunakan Treynor Ratio yang terdiri atas model Treynor Ratio dengan BI-Rate, serta 4 (empat) model Treynor Ratio lainnya, yaitu model tanpa suku bunga, model dengan zakat-rate, model dengan inflasi, dan model dengan gross domestic produc (GDP). Untuk memudahkan dan membedakan model yang satu dengan yang lain, penotasian persamaan (6) dimodifikasi sebagai berikut:

- Treynor Ratio dengan BI-Rate

- Treynor Ratio tanpa Suku Bunga

- Treynor Ratio dengan Zakat Rate

- Treynor Ratio dengan Inflasi

- Treynor Ratio dengan GDP

$$
\begin{aligned}
T R & =\left(\bar{R}_{t}-\bar{B}\right) / \beta_{t} \\
T R-N R F & =\left(\bar{R}_{t}\right) / \beta_{t} \\
T R-Z R & =\left(\bar{R}_{t}-\bar{Z}\right) / \beta_{t} \\
T R-I N F & =\left(\bar{R}_{t}-\bar{I}\right) / \beta_{t} \\
T R-G D P & =\left(\bar{R}_{t}-\bar{G}\right) / \beta_{t}
\end{aligned}
$$

dimana: $\bar{B}$ adalah mean BI-Rate, $\bar{Z}$ adalah Zakat Rate sebesar 2,5\%/(1-2,5\%) $=2,56 \% /$ tahun, $\bar{I}$ adalah mean Inflasi, dan $\bar{G}$ adalah mean GDP.

4. Tentukan rank saham masing-masing model berdasarkan hasil pada langkah 3 untuk setiap kelompok data.

5. Lakukan analisis kesesuaian 5 (lima) model modifikasi Treynor Ratio menggunakan uji Konkondansi Kendall's untuk keseluruhan model untuk setiap kelompok data yang statistik ujinya (Qudratullah, 2017):

dimana:

$$
W=\frac{12 \sum_{j=1}^{n} R_{j}^{2}-3 k^{2} n(k+1)}{k^{2} n\left(n^{2}-1\right)}
$$

$R_{j} \quad$ : jumlah Rank saham ke-j

$k \quad$ : banyak saham

$n \quad$ : banyak model

6. Hitung koefisien korelasi Spearman untuk setiap pasang model Treynor Ratio untuk setiap kelompok data (Qudratullah, 2017):

$$
r_{s}=1-\frac{6 \sum_{i=1}^{k} d_{i}^{2}}{n\left(n^{2}-1\right)}
$$

dimana:

$$
\begin{aligned}
& d_{i}=\left(R_{B_{i}}-R_{Z_{i}}\right) \\
& r_{s} \quad: \text { koefisien korelasi rank Spearman } \\
& R_{B_{i}} \quad: \text { rank saham ke- } i \text { dari variabel BI-Rate } \\
& R_{Z_{i}} \quad: \text { rank saham ke- } i \text { dari variabel Zakat-Rate }
\end{aligned}
$$

7. Buat scaterplot antara rank saham data pertama dan data kedua untuk 5 (lima) model, serta hitung nilai korelasi rank Spearmannya menggunakan persamaan (12).

8. Lakukan analisis kluster 5 (lima) model modifikasi Treynor Ratio untuk data gabungan. Analisis Kluster adalah analisis untuk mengelompokan elemen yang mirip sebagai objek penelitian menjadi kelompok yang berbeda dan mutually exclusive (Suprapto, 2004). Pengukuran kemiripan dan ketidak miripan antar objek dapat dilakukan dengan ukuran Euclidean yang secara umum dapat ditulis: 


$$
d=\sqrt{\left(x_{1}-x_{2}\right)^{2}+\left(y_{1}-y_{2}\right)^{2}}
$$

9. Buat grafik nilai kinerja 5 (lima) model Treynor Ratio untuk data gabungan.

\section{Hasil Analisis Data dan Pembahasan}

\section{Return dan Risiko Saham}

Terdapat 11 (sebelas) saham yang konsisten masuk JII periode Januari 2011 - Desember 2015. Berikut nilai mean return, standar deviasi, dan beta sahamnya.

Tabel 1. Return dan Risiko Data Pertama.

\begin{tabular}{llllll}
\hline No. & Kode & Nama Saham & Mean & Std. Deviasi & Beta \\
\hline 1 & AALI & Astra Agro Lestari tbk & $-0,001402$ & 0,097083 & 0,47365 \\
2 & ASII & Astra International tbk & 0,007077 & 0,071616 & 1,20024 \\
3 & ASRI & Alam Sutera Realty tbk & 0,005687 & 0,133452 & 2,03534 \\
4 & INTP & Indocement Tunggal Prakarsa tbk & 0,008735 & 0,085185 & 1,00223 \\
5 & KLBF & Kalbe Farma tbk & 0,015643 & 0,067057 & 0,92298 \\
6 & LPKR & Lippo Karawaci tbk & 0,011386 & 0,111678 & 1,32108 \\
7 & LSIP & PP London Sumatera tbk & $-0,005512$ & 0,136616 & 0,75989 \\
8 & SMGR & Semen Gresik (Persero) tbk & 0,007613 & 0,080079 & 1,38468 \\
9 & TLKM & Telekomunikasi Indonesia tbk & 0,016026 & 0,061762 & 0,56776 \\
10 & UNTR & United Tractors tbk & $-0,000284$ & 0,081653 & 0,89013 \\
11 & UNVR & Unilever Indonesia tbk & 0,016896 & 0,063775 & 0,12674 \\
12 & IHSG & Indeks Harga Saham Gabungan & 0,005048 & 0,041172 & 1,000000 \\
\hline
\end{tabular}

Tabel 2. Return dan Risiko Data Kedua.

\begin{tabular}{llllll}
\hline No. & Kode & Nama Saham & Mean & Std. Deviasi & Beta \\
\hline 1 & AALI & Astra Agro Lestari tbk & $-0,008435$ & 0,084529 & 0,01302 \\
2 & ASII & Astra International tbk & 0,003288 & 0,056214 & 1,46052 \\
3 & ASRI & Alam Sutera Realty tbk & $-0,001521$ & 0,077147 & 1,21221 \\
4 & INTP & Indocement Tunggal Prakarsa tbk & $-0,008415$ & 0,106237 & 2,18201 \\
5 & KLBF & Kalbe Farma tbk & $-0,003078$ & 0,063825 & 1,47644 \\
6 & LPKR & Lippo Karawaci tbk & $-0,034322$ & 0,089685 & 1,32248 \\
7 & LSIP & PP London Sumatera tbk & $-0,002551$ & 0,100004 & 0,02695 \\
8 & SMGR & Semen Gresik (Persero) tbk & $-0,008139$ & 0,073601 & 1,39115 \\
9 & TLKM & Telekomunikasi Indonesia tbk & 0,000237 & 0,065790 & 0,59147 \\
10 & UNTR & United Tractors tbk & 0,021894 & 0,080760 & 1,39992 \\
11 & UNVR & Unilever Indonesia tbk & 0,004663 & 0,057821 & 1,19492 \\
12 & IHSG & Indeks Harga Saham Gabungan & 0,007138 & 0,027963 & 1,000000 \\
\hline
\end{tabular}

Berdasarkan tabel 1, terdapat 8 (delapan) saham yang memiliki mean return positif dengan saham UNVR yang tertinggi dan terdapat 3 (tiga) saham yang memiliki nilai mean return negatif dengan saham LSIP yang terendah. Sedangkan saham yang memiliki volatilitas atau standar deviasi terendah adalah TLKM dan saham yang memilki volatilitas tertinggi adalah LSIP. Untuk nilai beta saham, terdapat 5 (lima) saham memilki beta saham di atas 1 (artinya saham ini memilki nilai volatilitas cenderung di atas harga pasar) dengan yang tertinggi adalah ASRI dan terdapat 6 (enam) saham yang memilki beta saham di bawah 1 (artinya sensifitas harga saham ini lebih kecil dari pasar) dengan yang terendah adalah UNVR. 
Tabel 3. Return dan Risiko Data Gabungan.

\begin{tabular}{llllll}
\hline No. & Kode & Nama Saham & Mean & Std. Deviasi & Beta \\
\hline 1 & AALI & Astra Agro Lestari tbk & $-0,003798$ & 0,092583 & 0,383431 \\
2 & ASII & Astra International tbk & 0,005786 & 0,066474 & 1,247480 \\
3 & ASRI & Alam Sutera Realty tbk & 0,003232 & 0,116922 & 1,875116 \\
4 & INTP & Indocement Tunggal Prakarsa tbk & 0,002893 & 0,092660 & 1,219563 \\
5 & KLBF & Kalbe Farma tbk & 0,009266 & 0,066221 & 1,020922 \\
6 & LPKR & Lippo Karawaci tbk & $-0,004185$ & 0,106450 & 1,304596 \\
7 & LSIP & PP London Sumatera tbk & $-0,004503$ & 0,124783 & 0,621220 \\
8 & SMGR & Semen Gresik (Persero) tbk & 0,002247 & 0,077884 & 1,379470 \\
9 & TLKM & Telekomunikasi Indonesia tbk & 0,010647 & 0,063246 & 0,566400 \\
10 & UNTR & United Tractors tbk & 0,007271 & 0,081587 & 0,993937 \\
11 & UNVR & Unilever Indonesia tbk & 0,012729 & 0,061764 & 0,325217 \\
12 & IHSG & Indeks Harga Saham Gabungan & 0,005760 & 0,037053 & 1,000000 \\
\hline
\end{tabular}

Sementara itu, berdasarkan tabel 2, terdapat 4 (empat) saham yang memiliki mean return positif dengan saham UNTR yang tertinggi dan terdapat 7 (tujuh) saham yang memiliki nilai mean return negatif dengan saham LPKR yang terendah. Sedangkan saham yang memiliki volatilitas terendah adalah ASII dan saham yang memilki volatilitas tertinggi adalah INTP. untuk beta saham, terdapat 8 (delapan) saham yang memilki nilai beta di atas 1 dengan yang tertingi adalah INTP dan terdapat 3 (tiga) saham yang memilki beta saham di bawah 1 dengan yang terendah adalah AALI.

Berdasarkan data gabungan yang disajikan dalam tabel 3, terdapat 8 (delapan) saham yang memiliki mean return positif dengan saham UNVR yang tertinggi dan terdapat 3 (tiga) saham yang memiliki nilai mean return negatif dengan saham LSIP yang terendah. Sedangkan saham yang memiliki volatilitas terendah adalah UNVR dan saham yang memilki volatilitas tertinggi adalah INTP. Untuk beta saham, gabungan terdapat 6 (enam) saham yang memilki nilai beta diatas 1 dengan yang tertingi adalah ASRI dan terdapat 5 (lima) saham yang memilki beta saham di bawah 1 dengan yang terendah adalah UNVR.

\section{Nilai dan Ranking Saham dengan Model Treynor Ratio}

Pada data pertama, kelima model sama-sama menempatkan UNVR, TLKM, KLBF, ASRI, dan UNTR pada peringkat 1, 2, 3, 8, dan 9. Sedangkan peringkat lainnya terdapat sedikit perbedaan, misalkan model TR, TR-ZR, TR-INF, dan TR-GDP menempatkan LPKR pada peringkat 4 dan INTP pada peringkat 5, sedangkan model TR-NRF sebaliknya.

Tabel 4. Nilai dan Peringkat Kinerja Model Modifikasi Treynor Ratoi Data Pertama.

\begin{tabular}{|c|c|c|c|c|c|c|c|c|c|c|}
\hline \multirow{2}{*}{ KODE } & \multicolumn{2}{|l|}{ TR } & \multicolumn{2}{|l|}{ TR - NRF } & \multicolumn{2}{|l|}{ TR - Z R } & \multicolumn{2}{|l|}{ TR - INF } & \multicolumn{2}{|l|}{ TR - GDP } \\
\hline & Nilai & Rank & Nilai & Rank & Nilai & Rank & Nilai & Rank & Nilai & Rank \\
\hline AALI & $-0,01491$ & 11 & $-0,00296$ & 10 & $-0,00747$ & 10 & $-0,01331$ & 10 & $-0,01202$ & 10 \\
\hline ASII & 0,001181 & 7 & 0,005896 & 6 & 0,004116 & 6 & 0,00181 & 7 & 0,002322 & 7 \\
\hline ASRI & 0,000013 & 8 & 0,002794 & 8 & 0,001744 & 8 & 0,000385 & 8 & 0,000686 & 8 \\
\hline INTP & 0,003068 & 5 & 0,008716 & 4 & 0,006584 & 5 & 0,003822 & 5 & 0,004435 & 5 \\
\hline KLBF & 0,010817 & 3 & 0,016948 & 3 & 0,014633 & 3 & 0,011635 & 3 & 0,0123 & 3 \\
\hline LPKR & 0,004334 & 4 & 0,008619 & 5 & 0,007001 & 4 & 0,004906 & 4 & 0,005371 & 4 \\
\hline LSIP & $-0,0147$ & 10 & $-0,00725$ & 11 & $-0,01007$ & 11 & $-0,01371$ & 11 & $-0,0129$ & 11 \\
\hline SMGR & 0,001411 & 6 & 0,005498 & 7 & 0,003955 & 7 & 0,001956 & 6 & 0,0024 & 6 \\
\hline TLKM & 0,018257 & 2 & 0,028226 & 2 & 0,024462 & 2 & 0,019588 & 2 & 0,020669 & 2 \\
\hline UNTR & $-0,00668$ & 9 & $-0,00032$ & 9 & $-0,00272$ & 9 & $-0,00583$ & 9 & $-0,00514$ & 9 \\
\hline UNVR & 0,088654 & 1 & 0,133308 & 1 & 0,11645 & 1 & 0,094614 & 1 & 0,099458 & 1 \\
\hline
\end{tabular}


Tabel 5. Nilai dan Peringkat Kinerja Model Modifikasi Treynor Ratio Data Kedua.

\begin{tabular}{|c|c|c|c|c|c|c|c|c|c|c|}
\hline \multirow{2}{*}{ KODE } & \multicolumn{2}{|l|}{ TR } & \multicolumn{2}{|l|}{ TR - NRF } & \multicolumn{2}{|c|}{ TR - Z RATE } & \multicolumn{2}{|l|}{ TR - INF } & \multicolumn{2}{|l|}{ TR - GDP } \\
\hline & Nilai & Rank & Nilai & Rank & Nilai & Rank & Nilai & Rank & Nilai & Rank \\
\hline AALI & $-1,06653$ & 11 & $-0,64758$ & 11 & $-0,81163$ & 11 & $-0,87636$ & 11 & $-0,86717$ & 11 \\
\hline ASII & $-0,00149$ & 3 & 0,002251 & 3 & 0,000788 & 3 & 0,000211 & 3 & 0,000293 & 3 \\
\hline ASRI & $-0,00576$ & 4 & $-0,00125$ & 5 & $-0,00302$ & 4 & $-0,00371$ & 4 & $-0,00361$ & 4 \\
\hline INTP & $-0,00636$ & 6 & $-0,00386$ & 7 & $-0,00484$ & 7 & $-0,00522$ & 7 & $-0,00517$ & 7 \\
\hline KLBF & $-0,00578$ & 5 & $-0,00209$ & 6 & $-0,00353$ & 6 & $-0,0041$ & 5 & $-0,00402$ & 5 \\
\hline LPKR & $-0,03008$ & 9 & $-0,02595$ & 9 & $-0,02757$ & 9 & $-0,02821$ & 9 & $-0,02812$ & 9 \\
\hline LSIP & $-0,29709$ & 10 & $-0,09464$ & 10 & $-0,17391$ & 10 & $-0,20519$ & 10 & $-0,20075$ & 10 \\
\hline SMGR & $-0,00977$ & 8 & $-0,00585$ & 8 & $-0,00739$ & 8 & $-0,00799$ & 8 & $-0,00791$ & 8 \\
\hline TLKM & $-0,00883$ & 7 & 0,000401 & 4 & $-0,00321$ & 5 & $-0,00464$ & 6 & $-0,00444$ & 6 \\
\hline UNTR & 0,011741 & 1 & 0,015639 & 1 & 0,014113 & 1 & 0,013511 & 1 & 0,013596 & 1 \\
\hline UNVR & $-0,00066$ & 2 & 0,003903 & 2 & 0,002114 & 2 & 0,001409 & 2 & 0,001509 & 2 \\
\hline
\end{tabular}

Pada data kedua, kelima model sama-sama menempatkan UNTR, UNVR, ASII, LPKR, LSIP, dan AALI pada peringkat 1, 2, 3, 9, 10, dan 11, sedangkan untuk peringkat 4 sampai 8 terdapat sedikit perbedaan.

Tabel 6. Nilai dan Peringkat Kinerja Model Modifikasi Treynor Ratio Data Gabungan.

\begin{tabular}{lllllllllll}
\hline \multirow{2}{*}{ KODE } & TR & \multicolumn{3}{c}{ TR - NRF } & \multicolumn{2}{l}{ TR - Z RATE } & TR - INF & \multicolumn{2}{c}{ TR - GDP } \\
\cline { 2 - 11 } & Nilai & Rank & Nilai & Rank & Nilai & Rank & Nilai & Rank & Nilai & Rank \\
\hline AALI & $-0,02449$ & 11 & $-0,00991$ & 11 & $-0,01548$ & 11 & $-0,02099$ & 11 & $-0,01982$ & 11 \\
ASII & 0,000157 & 5 & 0,004638 & 5 & 0,002926 & 5 & 0,001233 & 5 & 0,00159 & 5 \\
ASRI & $-0,00126$ & 6 & 0,001723 & 7 & 0,000584 & 7 & $-0,00054$ & 6 & $-0,00031$ & 6 \\
INTP & $-0,00221$ & 7 & 0,002372 & 6 & 0,00062 & 6 & $-0,00111$ & 7 & $-0,00075$ & 7 \\
KLBF & 0,0036 & 3 & 0,009076 & 3 & 0,006983 & 3 & 0,004914 & 3 & 0,00535 & 3 \\
LPKR & $-0,00749$ & 9 & $-0,00321$ & 9 & $-0,00485$ & 9 & $-0,00647$ & 9 & $-0,00612$ & 9 \\
LSIP & $-0,01625$ & 10 & $-0,00725$ & 10 & $-0,01069$ & 10 & $-0,01409$ & 10 & $-0,01337$ & 10 \\
SMGR & $-0,00242$ & 8 & 0,001629 & 8 & 0,00008 & 8 & $-0,00145$ & 8 & $-0,00113$ & 8 \\
TLKM & 0,008927 & 2 & 0,018798 & 2 & 0,015025 & 2 & 0,011297 & 2 & 0,012083 & 2 \\
UNTR & 0,001691 & 4 & 0,007315 & 4 & 0,005165 & 4 & 0,003041 & 4 & 0,003489 & 4 \\
UNVR & 0,021949 & 1 & 0,03914 & 1 & 0,03257 & 1 & 0,026076 & 1 & 0,027445 & 1 \\
\hline
\end{tabular}

Sementara itu, untuk data gabungan kelima model hampir sama menempatkan peringkat semua saham, yaitu dengan menempatkan UNVR, TLKM, KLBF, UNTR, ASII, SMGR, LPKR, LSIP, dan AALI pada peringkat 1, 2, 3, 4, 5, 8, 9, 10, dan 11. Sedikit perbedaan pada peringkat 6 dan 7, dimana model TR, TR-INF, dan TR-GDP menempatkan ASRI diperingkat 6 dan INTP diperingkat 7, sedangkan model TR-NRF dan TR-ZR sebaliknya.

\section{Analisis Kesesuaian Model Treynor Ratio}

Analisis kesesuaian hasil pengukuran kelima model Treynor Ratio dapat menggunakan uji Konkondansi Kendall's. Berdasarkan tabel 7, tampak bahwa koefisien kesesuaiannya sangat tinggi, yaitu 0,990 untuk data pertama, 0,985 untuk data kedua, dan 0,996 untuk data gabungan. Untuk melihat lebih detail, pada tabel 8 terlihat bahwa kombinasi semua pasangan sangat sesuai dan sempurna.

Tabel 7. Hasil Uji Kesesuaian Penilaian Model Treynor Ratio.

\begin{tabular}{lllll}
\hline Kelompok Data & Kendall's Coef. of Concordance & Chi-Square & Asymp. sig & Keterangan \\
\hline Data Pertama & 0,990 & 49,491 & 0,000 & Sangat sesuai \\
Data Kedua & 0,985 & 49,273 & 0,000 & Sangat sesuai \\
Data Gabungan & 0,996 & 49,782 & 0,000 & Sangat sesuai \\
\hline
\end{tabular}


Tabel 8. Koefisien Korelasi Antar Model Treynor Ratio.

\begin{tabular}{lllllll}
\hline \multirow{2}{*}{ Pasangan } & \multicolumn{2}{l}{ Data Pertama } & \multicolumn{2}{l}{ Data Kedua } & \multicolumn{2}{l}{ Data Gabungan } \\
\cline { 2 - 6 } & Nilai & Keterangan & Nilai & Keterangan & Nilai & Keterangan \\
\hline TR - TR NRF & $0,973^{*}$ & Sangat sesuai & $0,945^{*}$ & Sangat sesuai & $0,991^{*}$ & Sangat sesuai \\
TR - TR ZR & $0,982^{*}$ & Sangat sesuai & $0,973^{*}$ & Sangat sesuai & $0,991^{*}$ & Sangat sesuai \\
TR - TR INF & $0,991^{*}$ & Sangat sesuai & $0,991^{*}$ & Sangat sesuai & $1,000^{*}$ & Sempurna \\
TR - TR GDP & $0,991^{*}$ & Sangat sesuai & $0,991^{*}$ & Sangat sesuai & $1,000^{*}$ & Sempurna \\
TR NRF - TR ZR & $0,991^{*}$ & Sangat sesuai & $0,991^{*}$ & Sangat sesuai & $1,000^{*}$ & Sempurna \\
TR NRF - TR INF & $0,982^{*}$ & Sangat sesuai & $0,973^{*}$ & Sangat sesuai & $0,991^{*}$ & Sangat sesuai \\
TR NRF - TR GDP & $0,982^{*}$ & Sangat sesuai & $0,973^{*}$ & Sangat sesuai & $0,991^{*}$ Sangat sesuai \\
TR ZR - TR INF & $0,991^{*}$ & Sangat sesuai & $0,991^{*}$ & Sangat sesuai & $0,991^{*}$ Sangat sesuai \\
TR ZR - TR GDP & $0,991^{*}$ & Sangat sesuai & $0,991^{*}$ & Sangat sesuai & $1,000^{*}$ Sempurna \\
TR INF - TR GDP & $1,000^{*}$ & Sempurna & $1,000^{*}$ & Sempurna & $1,000^{*}$ & Sempurna \\
\hline
\end{tabular}

\section{Prediksi Model Modifikasi Treynor Ratio}

Untuk melihat kemampuan prediksi masing-masing model modifikasi Traynor Ratio dapat mengunakan scaterplot rank data pertama terhadap rank data kedua yang dilengkapi dengan nilai korelasi Spearmannya.
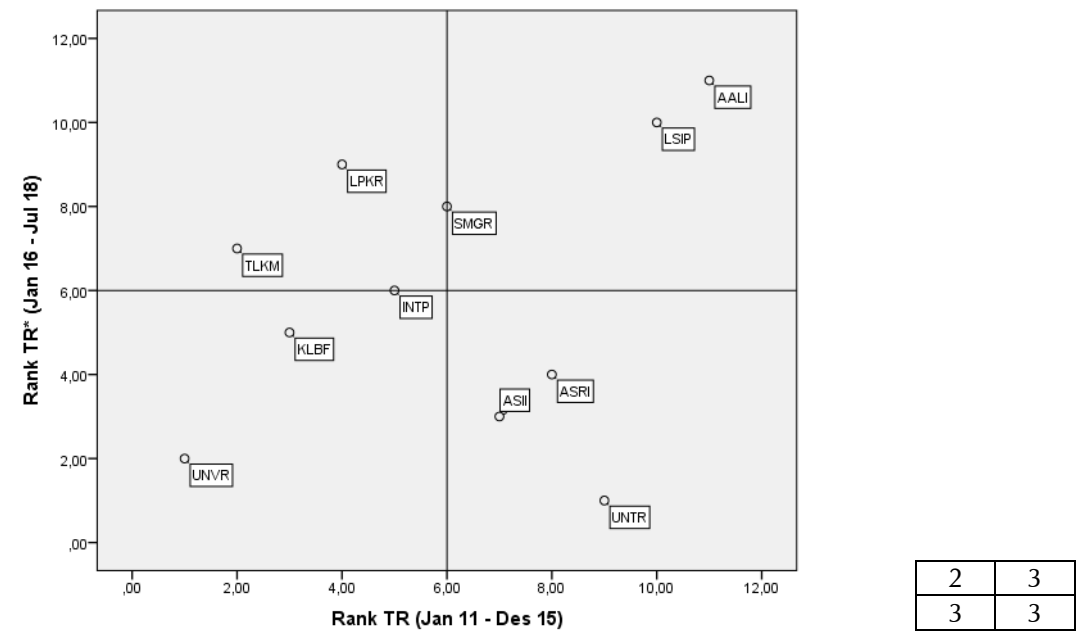

Rank Correlation Coefisient $=0,291(0,385)$

Gambar 2. Plot Rank Data Pertama dan Data Kedua pada Model TR dengan BI-Rate.
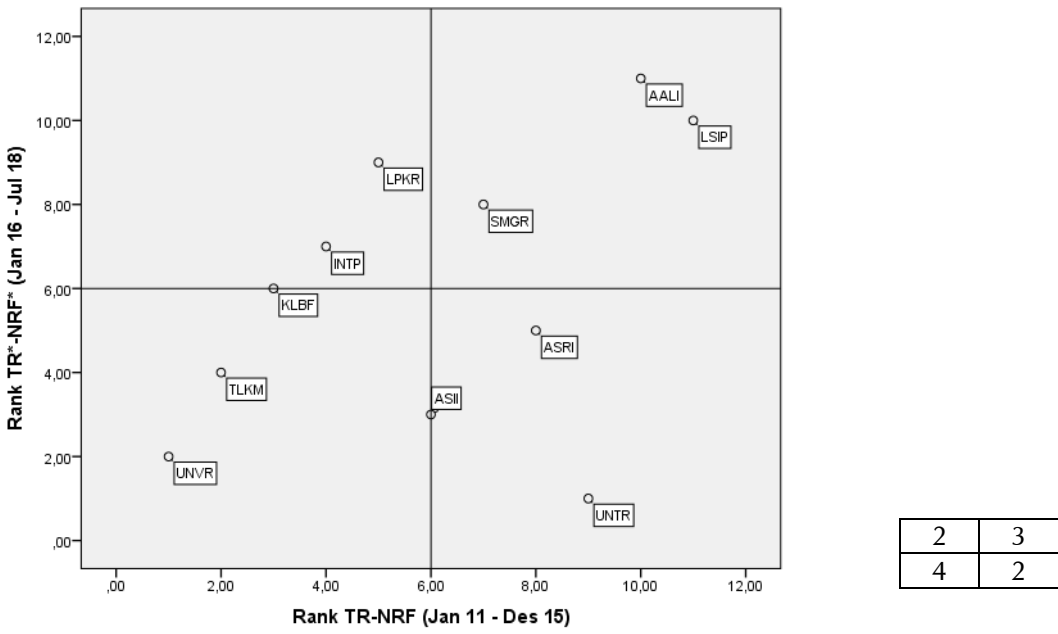

Rank Correlation Coefisient $=0,436(0,180)$

Gambar 3. Plot Rank Data Pertama dan Data Kedua pada Model TR Tanpa Suku Bunga. 

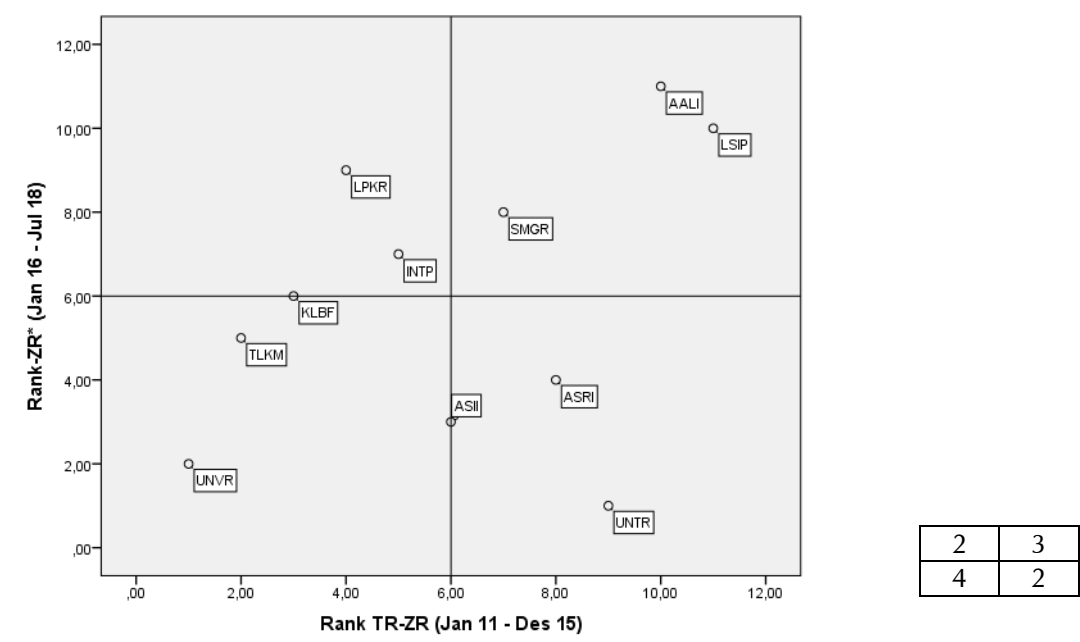

Rank Correlation Coefisient $=0,364(0,272)$

Gambar 4. Plot Rank Data Pertama dan Data Kedua pada Model TR dengan Zakat Rate.
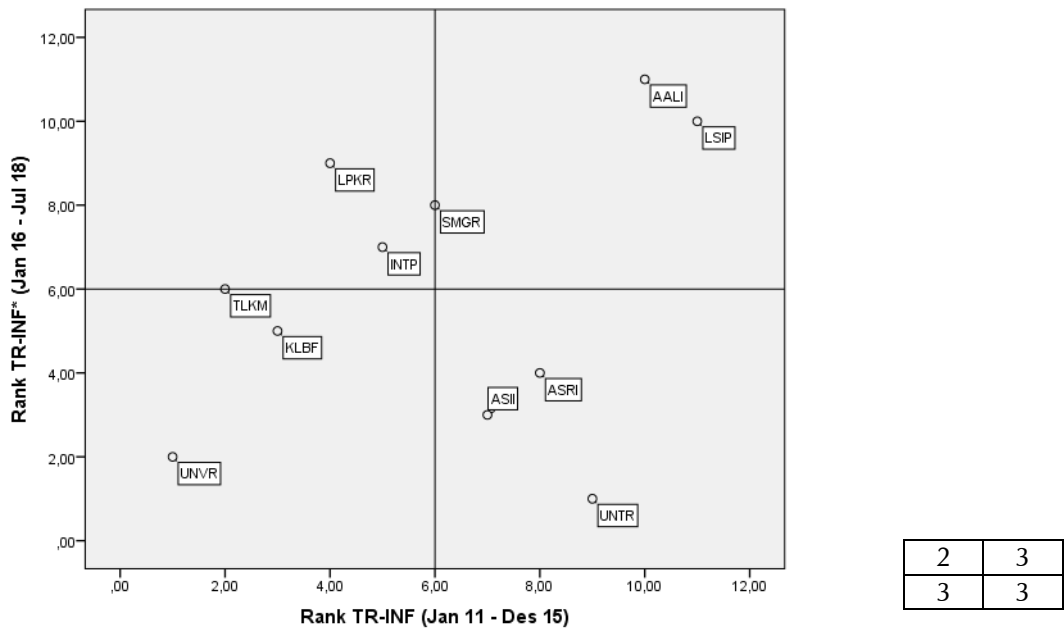

Rank Correlation Coefisient $=0,309(0,355)$

Gambar 5. Plot Rank Data Pertama dan Data Kedua pada Model TR dengan Inflasi.
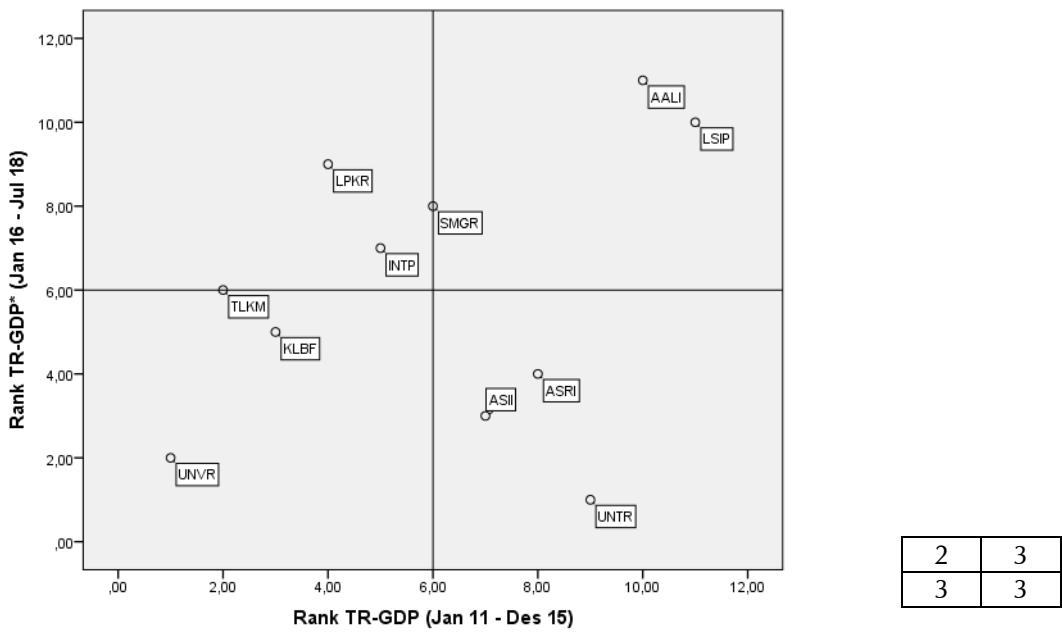

Rank Correlation Coefisient $=0,309(0,355)$

Gambar 6. Plot Rank Data Pertama dan Data Kedua pada Model TR dengan GDP. 
Berdasarkan Gambar 4, 5, dan 6, tampak bahwa ke-lima model memberikan nilai koefisien yang digolongkan lemah dan tidak signifikan, ini berarti tidak terdapat kesesuaian pengukuran pada data pertama dan kedua, dengan kata lain kemampuan prediksi kelima model tersebut adalah rendah dan tidak ada jaminan bahwa saham yang kinerjanya baik pada periode pertama akan baik juga pada periode kedua atau sebaliknya Dilihat dari persebaran jumlah saham berdasarkan kuadrannya, tampak bahwa Model TR-NRF dan Model TR-ZR memilki persebaran dan komposisi yang sama. Sedangkan Model TR, Model TR-INF, dan Model TR-GDP memilki persebaran yang sama, namun komposisi sedikit berbeda pada saham TLKM dan INTP.

\section{Analisis Kluster Model Treynor Ratio}

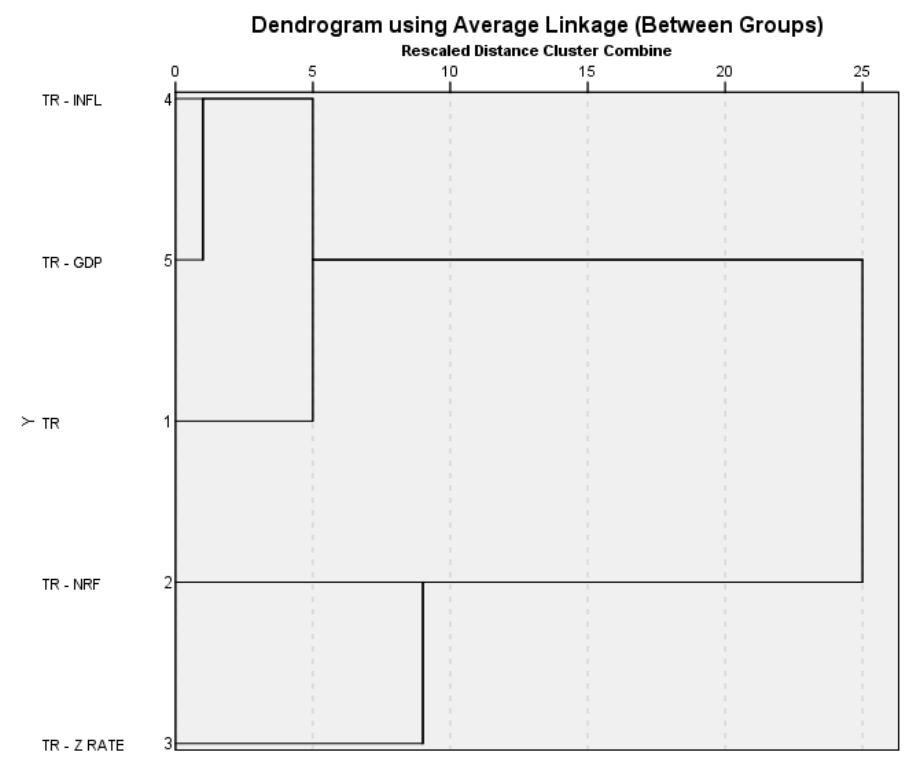

Gambar 7. Dendogram Analisis Kluster Model TR.

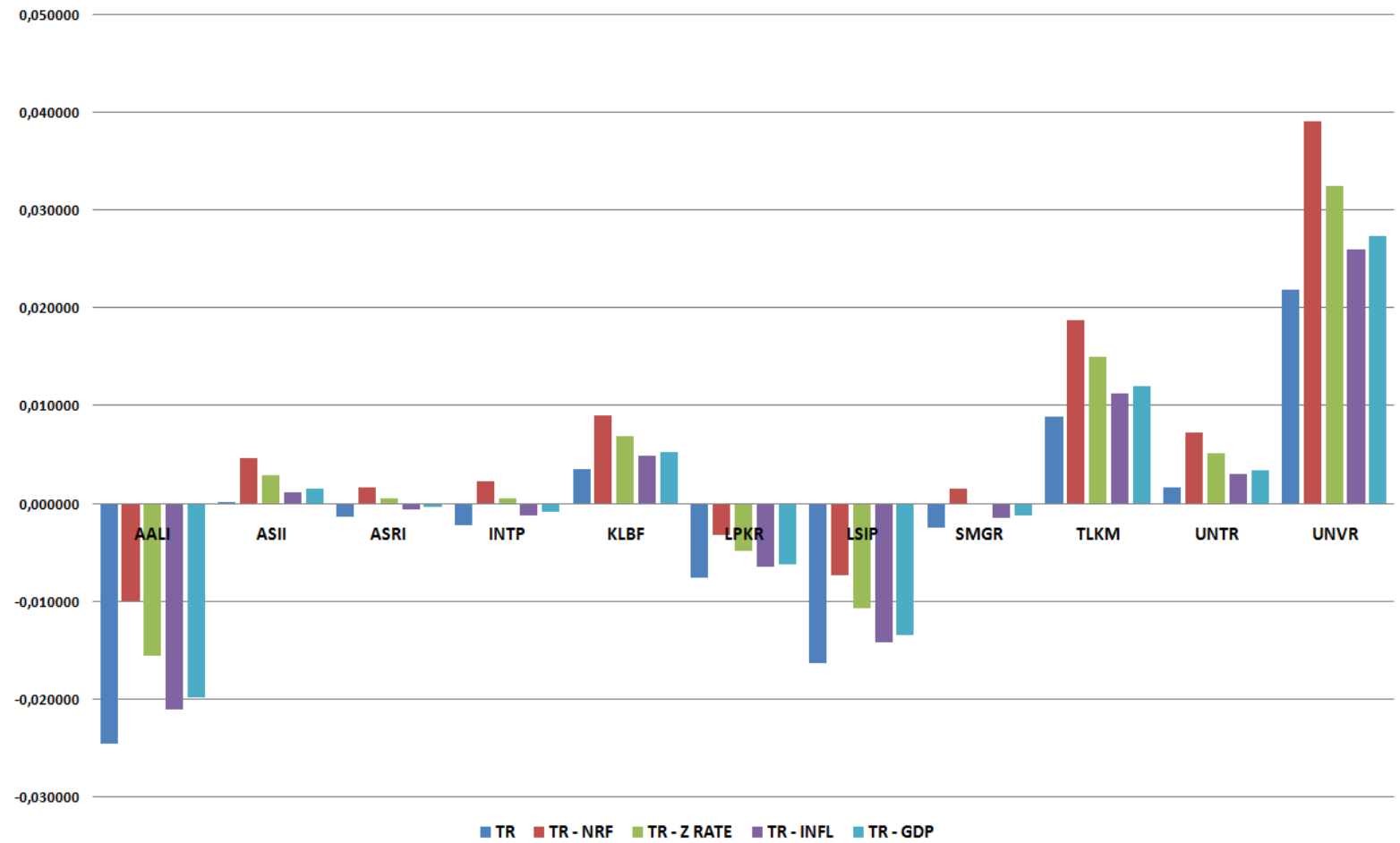

Gambar 8. Grafik Penguran Kinerja Model Treynor Ratio. 
Analisis kluster dilakukan untuk mengelompokan kelima model Treynor Ratio kedalam beberapa kelompok yang paling sesuai berdasarkan hasil pengukurannya. Berdasarkan dendogram pada gambar 7, kelima model Treynor Ratio dapat di kelompokan menjadi 2 (dua) kluster, yaitu kluster pertama terdiri atas model TR, model TR-INF, dan model TR-GDP, serta kluster kedua terdiri atas model TRNRF dan model TR-ZR. Hal ini didukung oleh gambar 8, khususnya pada hasil pengukuran kinerja pada saham ASRI, INTP, dan SMGR, tampak bahwa model TR, TR-INF, dan TR-GDP memberikan nilai yang negatif sedangkan TR-NRF dan TR-ZR memberikan nilai yang positif, selain itu nilainya yang cenderung berdekatan.

\section{Kesimpulan}

Tulisan ini membahas variabel alternatif untuk mendekati return bebas risiko selain dengan suku bunga (BI-Rate), yaitu dengan 4 (empat) pendekatan, yaitu: menghilangkan suku bunga, mengganti dengan zakat rate, mengganti dengan inflasi, dan mengganti dengan gross domestic produc (GDP) untuk mengukur kinerja saham syariah mengunakan model Treynor Ratio yang selanjutnya diimplementasikan pada pasar modal syariah di Indonesia periode Januari 2011 - Juli 2018. Beberapa kesimpulan yang diperoleh adalah:

1. Model Treynor Ratio dengan return bebas risiko didekati dengan suku bunga bersama model tanpa suku bunga, model dengan zakat rate, model dengan inflasi, dan model dengan GDP memilki nilai kesesuaian yang sangat tinggi, yaitu 0,990 untuk data pertama, 0,985 untuk data kedua, dan 0,996 untuk data gabungan.

2. Model Treynor Ratio dengan return bebas risiko didekati dengan suku bunga bersama model tanpa suku bunga, model dengan zakat rate, model dengan inflasi, dan model dengan GDP memilki mampuan prediksi dan tidak signifikan, berturut-turut nilainya adalah $0,291,0,436,0,364,0,309$, dan 0,309 .

3. Model Treynor Ratio dengan return bebas risiko didekati dengan suku bunga bersama model tanpa suku bunga, model dengan zakat rate, model dengan inflasi, dan model dengan GDP dapat dikelompokan jadi 2 (dua) berdasarkan kedekatan hasil pengukuran kinerjanya, yaitu: kelompok pertama atas model dengan suku bunga, model dengan inflasi, dan model dengan GDP, sedangkan kelompok kedua terdiri atas model tanpa suku bunga dan model dengan zakat-rate.

\section{Referensi}

[1] Andhyka, B., 2017. Sharia Equity Fund Performance Analysis (Indonesia's Case Study). IOSR-JBM: Journal of Bisiness and Management. Volume 19, issue 11, Ver. VI (november 2017). PP 22-23

[2] Ashraf, D., 2013. Performance evaluation of Islamic mutual funds relative to conventional funds: Empirical evidence from Saudi Arabia, International Journal of Islamic and Middle Eastern Finance and Management, Vol. 6 Issue: 2, pp.105-121,

[3] Ayub, M., 2009. Understanding Islamic Finance: A-Z Keuangan Islam. Jakarta: PT. Gramedia Pustaka Utama.

[4] Batuparan, D.S., 2000. BEI NEWS: Mengapa Risk Management? Edisi 4. Jakarta: Bursa Efek Indonesia (BEI)

[5] Djaddang, S., dan Susilawati, 2016. Kinerja Saham Syariah dan Konvensional: Aplikasi Model Jensen. Jurnal Organisasi dan Manajemen, Volume 12, No. 2, September 2016, 149-168

[6] El-Ashker, A. A. F., 1987. The Islamic Business Enterprise. London: Croom Helm

[7] Hamzah, A., dan Yohanes, A., 2014. Analisis Perbandingan Kinerja Reksa Dana Syariah dengan Reksadan Konvensional Jenis Saham pada Periode 2008-012. Jurnal MIX, Volume IV, No. 3, Okt 2014. Hal: 396-409

[8] Hanafi, M. M., dan Hanafi, S.M., 2012. 'Perbandingan Kinerja Investasi Syariah dan Konvensional: Studi pada Jakarta Islamic Indeks (III) dan Indeks LQ45'. Ekbisi: Jurnal Ekonomi dan Bisnis Islam Vol. VII. No.1

[9] Hanif, M., 2011. Risk and Return under Sharia Framework an Attempt to Develop Sharia Compliant Asset Pricing Model SCAPM. Pakistan Joural of Commerce and Social Scinces 5:2

[10] Hasbullah, E. S., Mohd, I. B., Mamat, M., Sukono., Rusyaman., E., 2013. Analisis Perbandingan beberapa Saham Syariah dengan Menggunakan Model Volatilitas Tak Konstan. Statistika Vol 13 No 1 Mei 2013. Hal: 25-31

[11] Huda, N., 2017. Analisis Perbandingan Kinerja Reksadana Saham Syariah dan Konvensional periode 2012-2015. Iqtishadia: Jurnal Kajian Ekonomi dan Bisnis Islam. Volume 10 No. 22017

[12] Jansen, M. C., 1967. 'The Performance of Mutual Funds in The Period 1945-1964. Journal of Finance, Vol. 23 No.2

[13] Jogiyanto, H., 2007. Teori Portofollio dan Analisis Investasi, Edisi kelima. Yogyakarta: BPEE

[14] Kurniawan, R. D., dan Asandimitra, N., 2014. Analisis perbandingan Kinerja Saham Syariah dan Kinerja Saham Konvensional. Jurnal Manajemen, Volume 2 Nomor 4 Oktober 2014. 
[15] Kusumawati, R., 2016. Analisis Reksadana Konvensional dan Reksadana Syariah dengan Menggunakan Metode Sharpe. Jurnal Info Artha. Vol. 4 Edisi Juli 21016. Page: 151-170

[16] Lestari, W. R., 2015. Kinerja Reksadana Saham Syariah dan Reksadana Saham Konventional. Jurnal Magister Managemen. Vol. 01. No. 1 Januari 2015

[17] Mansor, F., Bhatti, M. I., 2011. The Islamic Mutual Fund Performance: New Evidence on Market Timing and Stock Selectivity. International Conference on Economics and Finance Research (ICEFR 2011).

[18] Merdad, H., Hassan, M. K., dan Alhenawi, Y., 2010. Islamic Versus Conventional Mutual Funds Performance in Saudi Arabia: A Case Study. JKAU: Islamic Econ., Vol 23. No. 2, pp: 157-193

[19] Otoritas Jasa Keuangan Republik Indonesia. 2018. Statistik Pasar Modal Syariah Indonesia: Juli 2018. http://www.ojk.go.id/

[20] Qudratullah, M. F., 2017. Statistik Nonparametik: Teori Contoh Kasus dan Aplikasi dengan SPSS . Yogyakarta: Penerbit Andi

[21] Redman, L. A., Gullet, N. S., \& Manakyan, H. 2000. The performance of global and international mutual funds. Journal of Financial and Strategic Decisions, 13(1), 75-85.

[22] Rumintang, A. G., dan Azhari, M., 2015. Comparative Analysis of Performance of Conventional Equity Fund and Syariah Equyty Fund using Sharpe, Treynor, and Jansen Method in 2014. e-Proceeding of Management: Vol.2, No.2, Agustus 2015

[23] Setiawan, C., and Oktariza, H., 2013. Syariah and Conventional Stocks Performance of Public Companies Listed on Indonesia Stock Exchange. Journal of Finance and Economics. Vol. 3. No. 1. Jully 2013. Pp. 51-64

[24] Sharpe, W. F., 1966. 'Mutual Fund Performance'. The Jurnal of Business. Vol. 39. No. 1 Part:2

[25] Sheikh, S. A. 2010. Corporate Finance in an Interest Free Economy: An Alternate Approach to Practiced Islamic Corporate Finance.

[26] Sudarsono, H., 2003. 'Bank dan Lembaga Keuangan Syariah'. Edisi 2. Penerbit Ekonisia Kampus Fakultas FE UII Yogyakarta

[27] Suprapto, J. 2004. 'Analisis Multivariat Arti dan Interpretasi'. Jakarta: Rineka Cipta

[28] Tandelilin, E., 2001, Analisis Investasi dan Manajemen Portofolio'. Edisi Pertama, Yogyakarta: BPFE-Yogyakarta

[29] Tomkins, C., \& Karim, R. A. A. 1987. The Shariah and Its Implications for Islamic Financial Analysis: An Opportunity to Study Interactions Among Society, Organization and Accounting. The American Journal of Islamic Social Sciences, 4(1), 101-115. 2016. 69-82

[30] Treynor, J. L., 1965. 'Haw to Rate Management of Investment Funds'. Harvard Business Review XLIII. pp 63-75

[31] Utami, R. dan Nugraha, M. P. K., 2011. Analisis Kinerja Saham Syariah dan Pengaruhnya terhadap Respon Pasar pada Perusahaan yang Tercatat di Jakarta Islamic Indeks. Jurnal Reviw Akuntansi dan Keuangan. Vo.1 No. 2. Oktober 2011. 161-172

[32] Van Horne, J. dan Wachowics, Jr., J. M., 1992. Fundamentals of Financial Management. Prentice-Hall International Edition, eigth edition.

[33] Wiesinger, A., 2010. Risk-Adjusted Performance Measurement - State of the Art. Switzerland: University of St. Gallen (HSG), St. Galllen 
THIS PAGE INTENTIONALLY LEFT BLANK 